\title{
Early Devonian (Emsian) hyolith Ottomarites discors (Barrande, 1867) with colour pattern
}

\author{
MARTIN VALENT \& JOHN M. MALINKY
}

Several specimens of the hyolith Ottomarites discors (Barrande, 1867) most probably from the Lower Devonian DalejeTřebotov Formation, Suchomasty Limestone from Koněprusy, near Beroun (Prague Basin, Barrandian), exhibit distinct colouration on the venter of the conch and exterior of the operculum. These markings are developed as irregular brick-red concentric bands that follow the growth lines. Ottomarites discors is the only known hyolith that seems to retain its original colour pattern. $\bullet$ Key words: Hyolitha, colour pattern, Devonian, Emsian, Prague Basin, Bohemia, Czech Republic.

VALENT, M. \& MALINKY, J.M. 2008. Early Devonian (Emsian) hyolith Ottomarites discors (Barrande, 1867) with colour pattern. Bulletin of Geosciences 83(4), 503-506 (1 figure). Czech Geological Survey, Prague. ISSN 1214-1119. Manuscript received March 4, 2008; accepted in revised form November 3, 2008; issued December 31, 2008.

Martin Valent, National Museum, Department of Palaeontology, Václavské náměstí 68, 11579 Praha 1, Czech Republic; martin_valent@nm.cz・John M. Malinky,San Diego City College, Physical Science Department, 1313 Park Boulevard, San Diego, CA 92131, USA; jmalinky@sbcglobal.net

About 180 genera of Palaeozoic fossil invertebrates with preserved colour markings are currently known (Hoare 1978, Boucot 1981, Mapes \& Hoare 1987, Kobluk \& Mapes 1989). These include trilobites, cephalopods, gastropods, brachiopods, bivalves, crinoids and crustaceans. The species Ottomarites discors (Barrande, 1867) from the Lower Devonian of the classic Barrandian area of the Czech Republic is the only hyolith known to retain traces of what appears to be pigmentation on the shell. This colour pattern was first illustrated and shortly described by Barrande (1867, pl. 16, figs 1-3) and later by Novák (1886, pl. 2, figs 22-25). Despite these works Ottomarites has not been listed in modern studies concerning colour marking (see Kobluk \& Mapes 1989). In this paper the colour pattern of Ottomarites discors is re-described based on newly examined specimens from the National Museum collection.

\section{Locality and material}

The studied specimens originates from the extensive collections of Joachim Barrande, Ottomar Pravoslav Novák and Ladislav Marek deposited in the National Museum, Prague. Only a small part of these collections were selected for this study (nine conchs: L32093, L32094, L32095, L40288, L40289, L40290, L40291, L40292 and L40348; three opercula: L32096, L32097 and L32099).

The examined specimens do not yield a great deal of information on the collecting sites. All specimens are designated as "Koněprusy" or "Konieprus" locality (see Chlupáč 1983). In the $19^{\text {th }}$ century, that name was used as a broad designation for a number of collecting sites on and in the vicinity of Zlatý kůn̆ hill south of the village of Koněprusy, near Beroun. Studied specimens of Ottomarites discors most probably come from the Lower Devonian Suchomasty Limestone, Daleje-Třebotov Formation, latest Zlíchovian-Dalejian stage (middle-upper Emsian stage).

\section{Description of colour patterns}

Colour markings on Ottomarites discors (Barrande, 1867) exist only as concentric bands; no radial patterns have been seen. The markings on the shells of Ottomarites discors are seen as irregularly spaced zones of brick-red colour, following the curved growth lines on the venter, and in some cases, completely covering the dorsum. Colouration on the opercula is also developed in the form of concentric bands, and the bands are similar to the markings on the conchs.

The boundaries between the red zones and the uncoloured shell tend to be irregular; the thickness of the zones is highly variable on the same specimen and even within the zone itself. The intensity of colour is also variable even within the band itself. Certain colour zones are not complete and do not extend over the entire width of the venter or the outer surface of the operculum. The red colour of the shells/opercula is limited by the margin of these pieces and does not pass into the surrounding limestone. Although the limestone itself is often coloured red, the colouration of the shell is always stronger. The red-brick colouration is caused by small amount of manganese and iron, overall less than 1\% (specimen L40348 analysed at the Czech Geological Survey in Prague - scanning electron microscope CamScan 3400 with EDS analyzer LinkISIS 300). 
Nine conchs with exposed ventral sides and three opercula were selected for the description given above from the large collection of Ottomarites discors (about 150 specimens) deposited in the National Museum, Prague. All are well preserved with venter intact in most; in several cases a portion of the ligula or apical region can be missing.

Specimen NM L40288 (Fig. 1D) consists of the venter with part of the ligula missing. The colour pattern is developed mainly on the ligula and indistinct colour bands are visible in the middle of the venter.

Specimen NM L32094 (Fig. 1E) consists of a reddish venter with dark red colour bands that irregularly traverse the entire venter. NM L32093 (Fig. 1F) was originally described by Barrande ("Arc traces on the surface are red coloured and extend over the whole width of conch"; 1867, pl. 16, figs 1,2). The venter is completely covered with distinct colour bands as is the ligula and other parts of the conch.

Specimen NM L32095 (Fig. 1G) has the best developed colour pattern in the entire collection. This specimen was also illustrated and described by Barrande ("Another larger sample that shows identical colour arcs"; 1867, pl. 16, fig. 3); its colour bands are sharply defined and more distinctive. The colour pattern is irregularly developed as on all above-mentioned specimens.

Another four specimens (NM L40289-L40292; Fig. $1 \mathrm{H}-\mathrm{K}$ ) show identical patterns but the colour bands are only darker grey in comparison to the rest of conch surface. These grey colour patterns are best developed on the ligula areas where they are readily visible. One individual (NM L40291; Fig. 1J) bears a dark red spot with poorly defined edges on the venter. This spot overlays the grey zones on the ligula but the zones remain visible and resemble strongly the distribution of colouration on specimen NM L32094 (Fig. 1E).

Three well-preserved opercula of Ottomarites discors are described herein. All specimens represent outer surfaces with fine radial ribs. NM L32099 (Fig. 1A) is a complete operculum with concentric fuzzy colour bands that extend over the entire operculum. This specimen was originally illustrated by Novák (1886, pl. 2, figs 22-25). The second specimen (NM L32097; Fig. 1B) is an incomplete operculum with only imperfectly developed colour bands, some of which are distinct only on the right part. This individual was originally illustrated by Barrande ("This operculum shows identical coloured bands as seen on conchs"; 1867, pl. 16, fig. 4). The third specimen (NM L32096; Fig. 1C) is a nearly complete operculum with well-developed concentric colour bands and fine growth lines. The colour pattern is less distinct on the right side but most of the colour bands extend completely over the operculum.

\section{Systematic palaeontology}

Class Hyolitha Marek, 1963

Order Hyolithida Sysoev, 1957

Family Pauxillitidae Marek, 1967

\section{Genus Ottomarites Marek \& Galle, 1976}

Type species. - Hyolithes discors Barrande, 1867; Suchomasty Limestone - Daleje-Třebotov Formation, Lower Devonian (Emsian), Prague Basin, Bohemia.

\section{Ottomarites discors (Barrande, 1867)}

Figure 1

1867 Hyolithes catenatus Barr.; Barrande, p. 77, pl. 13, figs 17-21.

1867 Hyolithes discors Barr.; Barrande, p. 80, 81, pl. 13, figs $12-16$ and pl. 16, figs $1-6$.

1886 Hyolithes discors Barr. - Novák, p. 10, 27, pl. 2, figs 18-25.

1891 Hyolithes catenatus Barr. - Novák, p. 6.

1891 Hyolithes discors Barr. - Novák, p. 16, pl. 5, figs 1-4.

1941 Hyolithes discors Barr. - Růžička, p. 4.

1946 Hyolithes catenatus Barrande, 1867. - Sinclair, p. 74.

1946 Hyolithes discors (Barrande, 1867). - Sinclair, p. 75.

1976 Ottomarites discors (Barrande, 1867). - Marek \& Galle, pp. 52, 53, fig. 3G.

Lectotype. - Barrande (1867) did not designate a holotype for this species, subsequently Marek \& Galle (1976) erected the genus Ottomarites but did not select a lectotype for the type species. Specimen L32103 (Barrande 1867, pl. 13, figs 12-16) is here designated lectotype (Suchomasty Limestone - Daleje-Třebotov Formation, locality "Koněprusy"). The venter and dorsum with well-developed sculpture are preserved in this specimen. The apical and apertural regions are missing. Specimen L32103 is stored in the collection of the National Museum, Prague.

Material. - Nine conchs with exposed ventral sides and three outer sides of opercula with well-preserved colouration were selected from the extensive collections stored in the National Museum, Prague (conchs: L32093, L32094, L32095, L40288, L40289, L40290, L40291, L40292 and L40348; opercula: L32096, L32097 and L32099).

Description. - Straight conch of medium size with high triangular cross-section. Venter is very moderately convex, dorsal side strongly inflated with only slightly convex slopes. Lateral edges sharp; well-developed relatively long ligula. Aperture is conspicuously octagonal with its dorsal margin arched forwards. Internal mould with two 

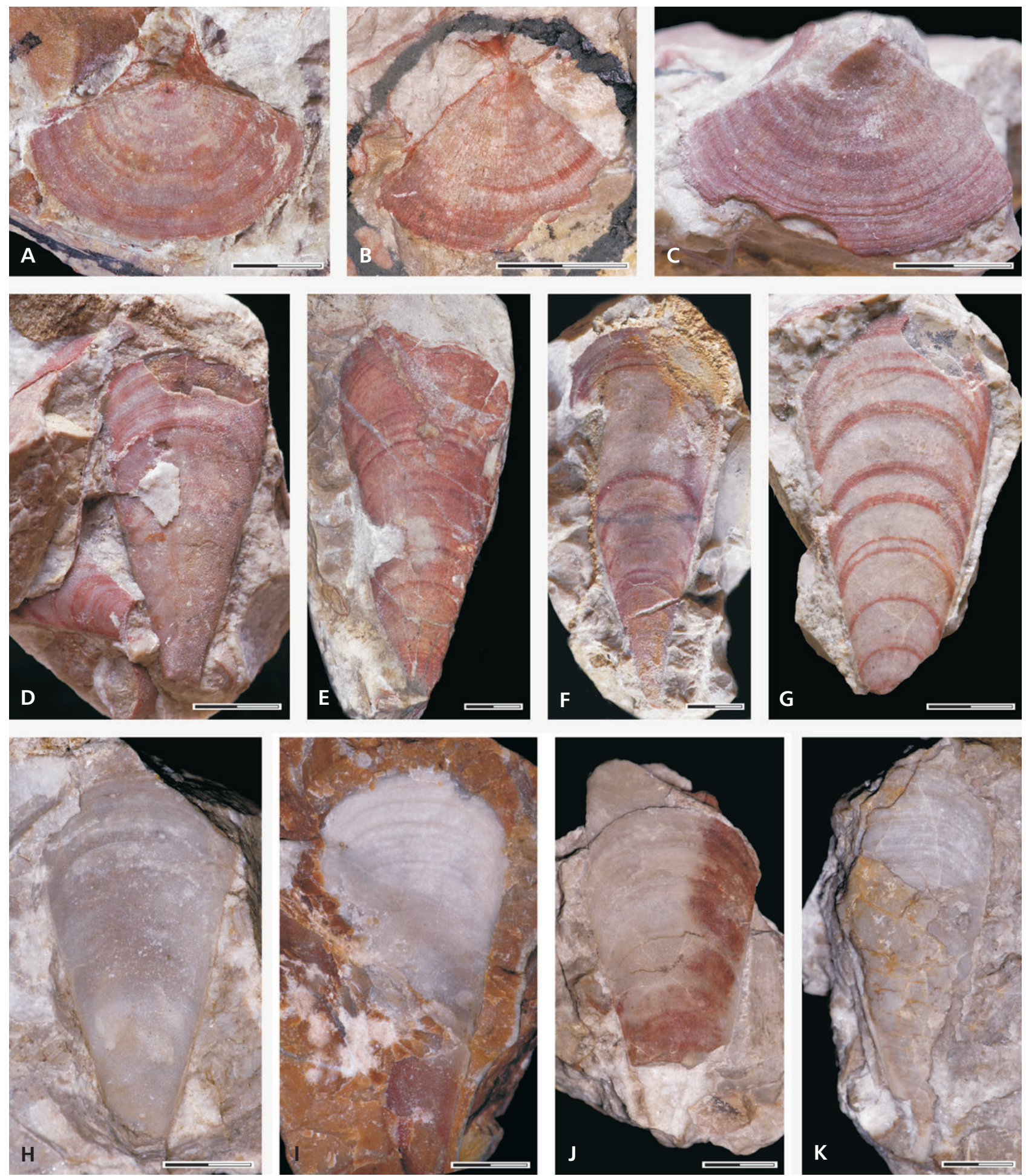

Figure 1. Ottomarites discors (Barrande, 1867). Lower Devonian, middle-upper Emsian stage, Daleje-Třebotov Formation, Suchomasty Limestone, locality "Koněprusy". • A - outer side of operculum, NM L32099 (originally illustrated by Novák 1886, pl. 2, figs 22-25). • B - outer side of operculum, NM L32097 (originally illustrated by Barrande 1867, pl. 16, fig. 4) • C - outer side of operculum, NM L32096. • D - venter, NM L40288. -E - venter, NM L32094. • F - venter, NM L32093 (originally illustrated by Barrande 1867, pl. 16, figs 1, 2) • G - venter, NM L32095 (originally illustrated by Barrande 1867, pl. 16, fig. 3). $\bullet$ H - venter, NM L40289. • I - venter, NM L40290. • J - venter, NM L40291. K - venter, NM L40292. Scale bars equal $5 \mathrm{~mm}$. 
longitudinal furrows situated close to the lateral margins. Dorsum is ornamented with fine longitudinal ribs; venter bears fine growth lines. Inner side of operculum bears two pairs of narrow clavicles. Cardinal processes not very long, leaf-shaped; central processes is short (sag.), broad (tr.). Lateral margins of the cardinal shield are almost straight. Outer surface bears fine radially arranged ribs.

Occurence. - Praha Formation: Dvorce-Prokop Limestone, Svatý Prokop Quarry, Praha-Hlubočepy; Loděnice Limestone, Branžovy Quarry near Loděnice. Daleje-Třebotov Formation, Suchomasty Limestone: locality "Koněprusy".

\section{Discussion and conclusions}

The colour patterns following the growth lines suggest their primary origin as shell pigmentation. Identical patterns are developed on both conchs and opercula and could indicate the accretion of these parts by the mantle, as this is common in molluscs. In this case the markings would probably have originated as pigment deposits (waste disposal) in the outer shell layer and later attained their red colouration during the fossilisation process. This opinion is supported by specimens lacking red colour but having a distinct and identical darker-grey pattern of arc bands. The surrounding limestone can also be red coloured (see Fig. 1I) but there is always a distinct border between the colours of the conch and the limestone itself.

Although it is difficult to determine the origin of the colouration, the hyolithid Ottomarites discors (Barrande, 1867 ) is so far the only representative of the entire Hyolitha with any preserved colour patterns on the shell. Lines of evidence cited above point rather to its biological origin.

\section{Acknowledgments}

The authors are indebted to V. Turek (National Museum, Prague) for discussion on several aspects of colour patterns; to O. Fatka (Charles University, Prague) for support during this research and to J. Kř́žz and Š. Manda (Czech Geological Survey, Prague) and R.H. Mapes (Ohio University, USA) for very inspirational comments in their reviews. The study was funded by project of the Ministry of Culture CR No. DE06P04OMG009 and project No. 246/2006 of the Grant Agency of Charles University in Prague.

\section{References}

BARRANDE, J. 1867. Systême silurien du centre de la Bohême. Ordre des Ptéropodes, 3. 179 pp. Privately published, Prague \& Paris.

BouCOT, A.J. 1981. Principles of benthic marine paleoecology. 463 pp. Academic Press, New York.

CHLUPÁČ, I. 1983. Stratigraphical position of Barrande's paleontological localities in the Devonian of Central Bohemia. Časopis pro mineralogii a geologii 28, 261-275.

HOARE, R.D. 1978. Annotated bibliography on preservation of color patterns on invertebrate fossils. The Compass, the Earth-Science Journal of Sigma Gamma Epsilon 55(3), 39-63.

KOBLUK, D.R. \& MAPES, R.H. 1989. The fossil record, function and possible origins of shell color patterns in Paleozoic marine invertebrates. Palaios 4, 63-85. DOI 10.2307/3514734

MAPES, R.H. \& HOARE, R.D. 1987. Annotated bibliography for preservation of color patterns in invertebrate fossils. The Compass, the Earth-Science Journal of Sigma Gamma Epsilon 65(1), 12-17.

MAREK, L. 1963. New knowledge on the morphology of Hyolithes. Sborník geologických věd, Paleontologie 1, 53-73.

MAREK, L. 1967. The Class Hyolitha in the Caradoc of Bohemia. Sborník geologických věd, Paleontologie 9, 51-113.

MAREK, L. \& GALLE, A. 1976. The tabulate coral Hyostragulum, an epizoan with bearing on hyolithid ecology and systematics. Lethaia 9, 51-64. DOI 10.1111/j.1502-3931.1976.tb00951.x

NovÁK, O. 1886. Zur Kenntniss der Fauna der Etage F-fl in der palaeozischen Schichtengruppe Böhmens. Aus den Sitzungsberichten der königlichen böhmens Gesellschaft der Wissenschaften, 1-27.

NOVÁK, O. 1891. Revision der palaeozoischen Hyolithiden Böhmens. Abhandlungen der mathematisch-naturwisschenschaftlichen Classe der böhmischen Gesellschaft der Wissenschaften, series 7(4), 1-48.

RŮŽIČKA, R. 1941. Faunistické seznamy z Barrandienu ze souvrství g $\alpha$ (Část II.) a ze dvou lokalit z g $\gamma$ v okolí Pražském. Věstník Královské České společnosti nauk 1941, 1-16.

SINCLAIR, G.W. 1946. Notes on the nomenclature of Hyolithes. Journal of Paleontology 20, 72-85.

SYSOEV, V.A. 1957. K morfologii, sistematike i sistematicheskomu polozheniyu khiolitov [To the morphology, systematics and systematic position of the Hyolithoidea]. Doklady Akademii nauk SSSR 116(2), 304-307. [in Russian] 